University of Nebraska - Lincoln

DigitalCommons@University of Nebraska - Lincoln

Congreso internacional sobre iconografía

precolombina, Barcelona 2019. Actas.

8-20-2020

Representaciones del ave e instrumentos rituales tiwanakotas.

Medios para llegar a lo divino

Elisa Cont

Follow this and additional works at: https://digitalcommons.unl.edu/actas2019

Part of the American Material Culture Commons, Indigenous Studies Commons, Museum Studies Commons, Other History of Art, Architecture, and Archaeology Commons, and the Other Languages, Societies, and Cultures Commons

This Article is brought to you for free and open access by the Zea E-Books at DigitalCommons@University of Nebraska - Lincoln. It has been accepted for inclusion in Congreso internacional sobre iconografía precolombina, Barcelona 2019. Actas. by an authorized administrator of DigitalCommons@University of Nebraska - Lincoln. 


\title{
Representaciones del ave e instrumentos rituales tiwanakotas. Medios para llegar a lo divino
}

\author{
Elisa Cont
}

Departamento de Arte. Universidad Autónoma de Barcelona (UAB), España.

Email: elisacont981@gmail.com

\begin{abstract}
Resumen
La representación del ave en la iconografía Tiwanaku es parte de un conjunto de símbolos sagrados, emblemas de poder, que condensan unos conocimientos acerca de la cosmovisión y estarían vinculados a prácticas chamánicas. La imagen del ave, representada por elementos simplificados como las alas, el vuelo o los ojos, simbolizaría la capacidad de atravesar las fronteras entre los mundos, de ver lo sagrado, y expresaría la intermediación entre hombres y divinidades. Esta investigación se propone analizar aquellos elementos iconográficos Tiwanaku que representan el ave y que se encuentran grabados sobre algunos objetos rituales de diferente material. Las imágenes plasmadas en estos instrumentos rituales poseen un valor especial: además de ser símbolos de conocimientos y saberes, se vuelven medios mágicos-simbólicos para llegar a lo divino.
\end{abstract}

Palabras claves: iconografía Tiwanaku, ave, instrumentos rituales, símbolos sagrados, cosmovisión

\begin{abstract}
The representation of the bird in the Tiwanaku iconography is part of a set of sacred symbols, emblems of power, that condense knowledge about the cosmovision and may be linked to shamanic practices. The image of the bird, represented by simplified elements, such as wings, flying or eyes, symbolizes the ability to cross the boundaries between the worlds, to see the sacred, and may express the intermediation between men and divinities. This research aims to analyze those Tiwanaku iconographic elements that represent the bird and that are engraved on some ritual objects of different material. The images
\end{abstract}

embodied on these ritual instruments have a special value: in addition to being symbols of knowledge, they become magicalsymbolic means to reach the divine.

Keywords: iconography Tiwanaku, bird, ritual instruments, sacred symbols, cosmovisión

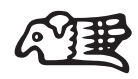

Este artículo es el resultado de una investigación transdisciplinaria, que incluye estudios de arqueología, antropología, semiótica y estética, y se propone analizar aquellos elementos iconográficos que representan y simbolizan el ave y que estarían vinculados a una práctica chamánica en la cultura Tiwanaku (400a.C-1150d.C.). Representaciones simbólicas que, pintadas, incisas, y tejidas en determinados materiales atribuyen a estos objetos un valor sagrado, convirtiéndolos en instrumentos rituales. La iconografía de la cultura Tiwanaku está compuesta por un sistema simbólico, un lenguaje icónico, que refleja su pensamiento mítico-espiritual a través de imágenes que están relacionadas lógicamente entre ellas. Cada icono tiwanakota encierra varios significados que no es posible interpretar aisladamente, al contrario, forma parte de un conjunto coherente y significativo. La iconografía Tiwanaku grabada arriba de determinados

Publicado en Congreso internacional sobre iconografía precolombina, Barcelona 2019. Actas, Victòria Solanilla Demestre, editora (Lincoln, Nebraska: Zea Books, 2020). https://doi.org/10.32873/unl.dc.zea.1255 
materiales rituales, sigue un propio orden de composición, una estructura, creando lenguajes simbólicos, mensajes mágicos divinos a través de los cuales los sacerdotes, chamanes u hombres de poder tiwanakotas podían comunicarse con las divinidades y trasmitir sus saberes.

Durante mi trabajo de campo en el Centro Ceremonial de Tiwanaku, en sus Museos Lítico y Cerámico y en el Museo de los Metales Preciosos de La Paz tuve la oportunidad de analizar diferente material de uso ritual tiwanakota, observando que en su iconografía estaban representados frecuentemente elementos vinculados a lo aviario con diferentes y especificas características.

\section{Las diferentes representaciones del ave y sus diversos significados}

Analizando los diversos iconos aviarios presentes en el arte Tiwanaku, emergen diferentes características entre ellos, demostrando una voluntad del artista tiwanakota en representar rasgos desiguales entre imágenes de aves. La diversidad entre representaciones aviarias sería la consecuencia de un profundo conocimiento de los artesanos acerca las especies y de la necesidad de transmitir diferentes mensajes. El hombre tiwanakota era un constante observador de la naturaleza y de los animales que habitaban sus territorios. El estilo naturalista del arte Tiwanaku estaba relacionado con esta observación, en el cual se grababan momentos y elementos significativos de la vida de la comunidad a través inconfundibles características geométricas.

De acuerdo con el estudioso Yacovleff, el punto de partida para interpretar el significado simbólico de los elementos aviarios en la iconografía es conocer las características morfológicas y las habilidades de las especies de aves representadas (Eugenio Yacovleff, 1932). Según estudios de ornitología las aves pertenecen a dos tipologías; las diurnas y las nocturnas. Las diurnas se dividen a su vez en dos familias: las falcónidas o aves de rapiña, especies cazadoras, y las vultúridas que se sostienen con carne de animales ya muertos. Las Falcónidas son voladoras fuertes y hábiles, dotadas de gran inteligencia. Se caracterizan por su pico relativamente corto, arqueado desde la base, garras grandes y el cuerpo totalmente emplumado. Las Vultúridas, entre las cuales se hallan los cóndores, están dotadas por una agudísima vista y grande capacidad de vuelo para alcanzar alturas muy elevadas de donde buscan su sustento. Esta especie no tiene garras grandes, pero está caracterizada por un cuello largo sin plumas, un pico largo y recto y un collar de plumas alrededor de la nuca, además los cóndores machos se diferencian de las hembras por tener cresta (ob.cit.).

Mediante el conocimiento de determinadas características es posible identificar cuál de los volátiles representaba el artesano tiwanakota en sus materiales y consecuentemente interpretar el mensaje que quería transmitir. Las aves de rapiña, los cóndores, los flamencos y algunas particulares aves de lago son las especies que se encuentran con más frecuencia en la iconografía Tiwanaku y están grabadas en instrumentos rituales, monumentos ceremoniales, modelados de cerámica y materiales textiles.

Las aves falcónidas se encuentran a menudo pintadas en la misma vasija juntos al felino, posicionadas en la parte debajo del anillo de decantación en los kerus. Estos iconos están caracterizados por un borde negro y una línea más gruesa amarilla que delinea el cuerpo con una forma geométrica que recuerda el símbolo escalonado. Se observa que, de acuerdo con Villanueva, las aves en la iconografía Tiwanaku suelen ser reducidas a un símbolo escalonado, cuyo remate en los materiales líticos es una cabeza de ave (Villanueva, 2015). La cola normalmente está dividida en dos, para indicar las plumas, frecuentemente pintadas de blanco y la cabeza mira hacia arriba, con ojos abiertos y pico blanco cerrado. A veces desde el pico suele bajar un signo serpenteado (Figura 1 y 2).

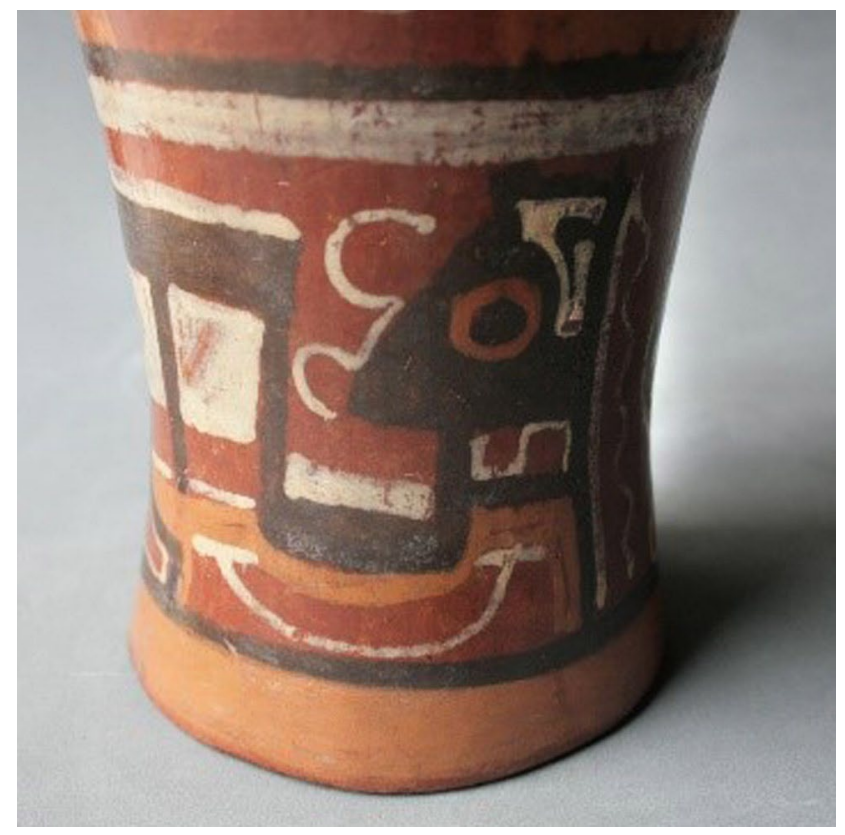

Figura 1 Keru Tiwanaku, Época IV. Colección Fritzbuch, Museo Metales Preciosos. La Paz, Bolivia (Fotografía Elisa Cont) 


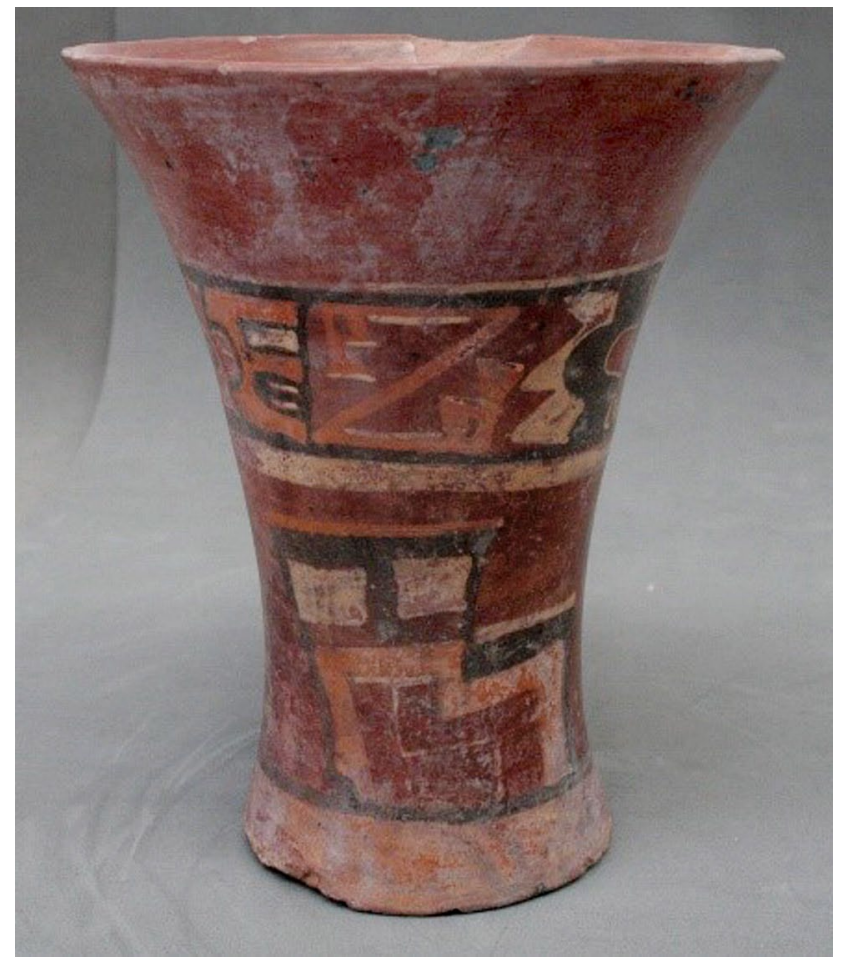

Figura 2 Keru Tiwanaku, época IV-V. Museo Cerámico, Tiahuanaco. La Paz, Bolivia (Fotografía Elisa Cont)

El ave pintada en el arte Tiwanaku podría ser lo que Bertonio en su Vocabulario de la Lengua Aymara describe con el nombre de "Checa Hanko Kacani": el pájaro que tiene blancas las puntas de las alas (Bertonio, 1555-1628).

Las representaciones de aves falcónidas y de cóndores se puede distinguir claramente por sus diferentes características. Las imágenes de vultúridas en las piezas cerámica son de simple identificación y en los kerus se encuentran generalmente en la parte superior, arriba de los anillos de decantación. Los cóndores están pintados en negro, generalmente de perfil, con alas bien delineadas a través de tres plumas blancas y rojizas en el centro del cuerpo, y a la altura del pecho está presente un círculo rojizo con punto negro en el interior o una calavera. El cuello es muy largo y negro y la cabeza está representada con pico blanco alargado, cresta blanca arriba y ojo abierto. Frecuentemente estas tipologías de aves están pintadas cerca de cuerpos humanos sin vida, comiendo algunas de sus partes, generalmente la cabeza. Alrededor de los cóndores vienen pintados cruces, círculos y

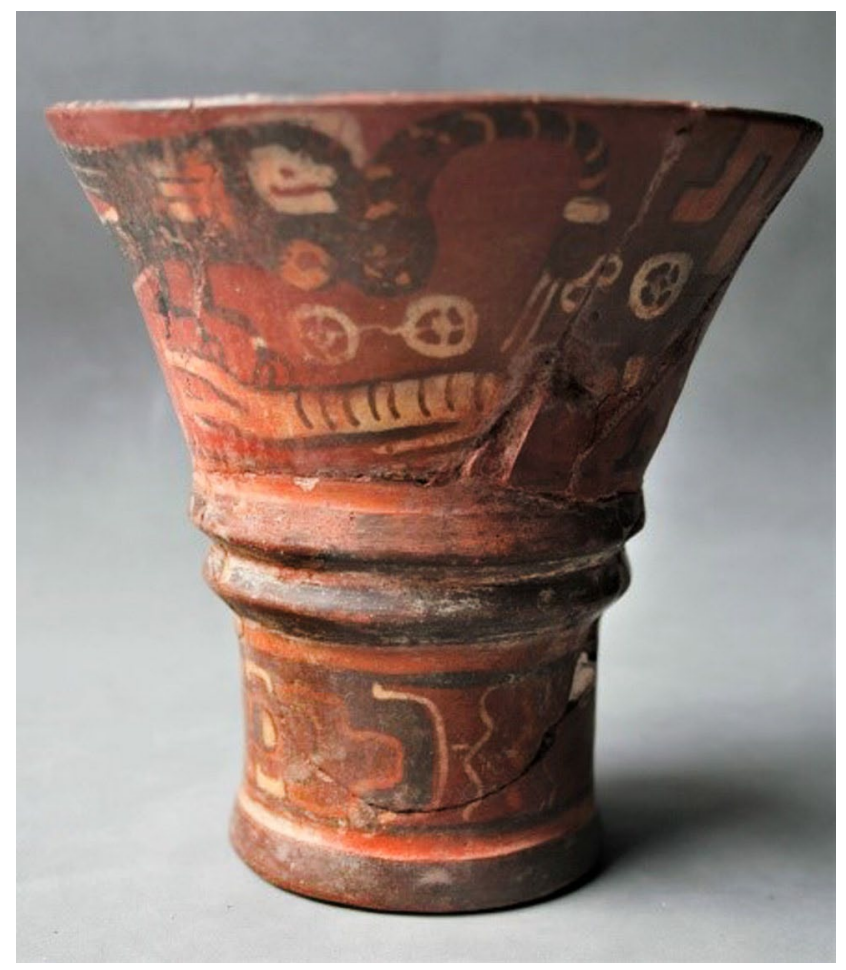

Figura 3 Keru Tiwanaku, Época V. Colección Buch, Museo Metales Preciosos. La Paz, Bolivia (Fotografía Elisa Cont)

serpentinas, de color blanco que según una primera hipotesis podrían indicar algunos astros o números (Figura 3). Bertonio, en su obra, describe con el nombre de Mamani Conturi Mayco el "Halcón, como Rey de los Pájaros" y "Señor de mucho va fallos, y especialmente llaman así cuando canta sus endechas ${ }^{1 \text { " relacionándolo a }}$ un hombre de poder (ob.cit.). Es posible que el autor lo describa como halcón por su escaso conocimiento sobre las especies aviarias del territorio andino, y por estos motivos podría referirse en verdad al cóndor. La palabra Mallku en lengua aymara actualmente tiene varios significados; si se refiere a los nombres Kuntur Mamani indicaría los cóndores que viven y vuelan en el altiplano andino y sus serranías. Por su vuelo en las alturas, el cóndor, animal majestuoso y respetado, simbolizaría la manera de gobernar desde las cumbres de las montañas. De aquí el significado del término Mallku Kunturi: el señor de la gran altura. Mallku Kunturi sería el animal que relaciona el mundo terrenal, de los hombres, el Akapacha, con el plano celestial, el Alajpacha (Mamani, 2003). A través de mi trabajo de campo noté que todavía en las 
comunidades de Tiahuanaco sigue vigente el nombre Mallku para denominar hombres con autoridad política, roles decisionales y liderazgo.

En la mayoría de las imágenes analizadas se nota un estrecho vínculo entre aves (ambas las especies) y los iconos de cabezas de perfil o "caras sueltas" que parecen estar evidenciando el típico ojo alado tiwanakota. Como hemos observado anteriormente, las aves, dependiendo de la especie, están pintadas en los kerus en la parte superior o inferior; las falcónidas en la parte inferior, y los cóndores en la parte superior. Hay que añadir a este análisis iconográfico que en la parte opuesta de sus imágenes en el keru se encuentran representadas caras de perfil o cabezas sueltas.

Las "cabezas sueltas", como las define la estudiosa Costas, solían ser reproducidas en específicos instrumentos rituales y juntas a determinadas imágenes, y en nuestro caso cerca de algunas especies de aves. Estos iconos se representaban sin las características típicas de la violencia ritual como en las cabezas trofeos, por el contrario, simbolizaban un elemento en vida y con ciertos atributos (pinturas faciales, dilataciones etc.). La cabeza era considerada símbolo del poder generador de la vida y fuente del orden cósmico. El conjunto de iconos, aves (falcónidas o vultúridas) con cabezas sueltas, podría ser interpretado como un lenguaje iconográfico donde el ave representaría el elemento de conexión entre los mundos y la cabeza, la "vida". Imágenes que juntas crearían un mensaje hacia lo divino para pedir la fertilidad de los cultivos y la continuidad del ciclo vital, visto el carácter agrario de la sociedad Tiwanaku.

En el material lítico Tiwanaku, a diferencia del cerámico, el ave no suele ser representada en figura entera, solo se encuentran grabados unos rasgos de ella: las plumas, las alas y las cabezas con pico. Las cabezas se pueden distinguir por dos tipologías: las cabezas con cresta y las sin cresta. Probablemente indicando el cóndor macho y el cóndor hembra, o las dos tipologías de aves anteriormente descritas; halcones y cóndores machos.

En la iconografía de la cultura Tiwanaku, como en las culturas Moche, Nazca y las otras culturas precolombinas, el ave tenía un rol importante evidenciado por su frecuente representación. El arqueólogo Posnansky fue entre los primeros estudiosos en reconocer la importancia del símbolo del ave y sus diversas variantes en la iconografía Tiwanaku, anotando en su obra "La cuna del hombre americano", que estas diferencias simbolizarían distintos significados (Posnanky, 1945). Como veremos más adelante, las aves y/o cóndores formaban parte de un conjunto de animales tutelares, animales guías y de poder, que los chamanes consideraban animales sagrados que les ayudaban a comunicarse con las divinidades. Además, la migración de algunas tipologías de aves hacía los territorios Andinos y alrededor del Lago Titicaca probablemente fue interpretada por los Tiwanakotas como indicador del arribo de las lluvias y un signo divino de abundancia de los cultivos y mejor sustento. Sin embargo, hasta el día de hoy hay escasas informaciones sobre los movimientos migratorios en los territorios altoandinos, pero recientes estudios ornitológicos han logrado individuar las aves residentes durante todo el año (95 especies), y las especies migratorias que llegan en diferentes temporadas del año en la cuenca del Lago Titicaca (40 especies) (Pulido Capurro, 2018). Mayores investigaciones sobre estos fenómenos migratorios podrían aclarar el vínculo entre aves y temporadas de sequias o lluvia y ciclos agrícolas, finalmente ayudando en la interpretación del significado de algunas especies de aves en la iconografía Tiwanaku.

\section{Instrumentos chamánicos Tiwanaku e iconografía del ave}

Los iconos Tiwanaku crean un mensaje mágico-divino único mediante sus formas, sus colores, su orden y el material en los cuales están grabados. El ave se puede encontrar representado en diferentes tipologías: en figura entera, a través de símbolos escalonados, mediante algunos elementos corporales (alas, cola, pico) o por imágenes que simbolizarían sus habilidades divinas (la vista y el vuelo). Es interesante notar como estas imágenes sean grabadas con una cierta frecuencia en instrumentos utilizados para el consumo de sustancias psicotrópicas en particular en tabletas inhalatorias y keros. Los keros y las tabletas inhalatorias son los objetos ceremoniales más representativos relacionados a los rituales chamánicos en la cultura Tiwanaku. Ambos eran considerados instrumentos sagrados y reflejaban la ideología y estructura de la sociedad Tiwanaku por ser objetos de uso exclusivo. Los keros son vasos en cerámica, madera o metales que se utilizaban para beber chica de maíz y consumir substancias psicotrópicas; como testimonian los documentos de los cronistas Polo de Ondegardo, Cobo y Guamán Poma, describiendo como la Vilca era añadida a diversos brebajes (Berenguer, 1987).

Las tabletas inhalatorias son generalmente elaboradas en madera, aunque se encontraron de piedra y hueso, tienen una cavidad plana, rectangular, redonda u ovoide con varias incisiones y tallados en volumen (Torres, 
1986). Estas tabletas se utilizaban para la preparación y consumo de sustancias psicoactivas en distintos rituales. La substancia visionaria que se relaciona con las tabletas, según los análisis hechos por Torres, es la misma consumida en los kerus y se trata de un polvo psicoactivo obtenido de las semillas de un árbol del género leguminoso "Anadenanthera A.columbrina" (Llangostera, 2006). Las semillas de esta planta eran de fácil acceso para los tiwanakotas, ya que su hábitat se encuentra en el noroeste de Argentina, donde es conocida como $\mathrm{Ce}$ bil o Sebil, y en Perú y Bolivia, donde es llamada Vilca o Huilca (Torres, 2004).

En la Colección Campagner, conservada en el Museo del Seminario Episcopal de Treviso, Italia, la estudiosa Laurencich-Minelli encontró magníficos ejemplos de tabletas inhalatorias tiwanakotas, provenientes del territorio Atacameño donde fueron esculpidos en tres dimensiones elementos aviarios. Entre varios objetos rituales analizados por la estudiosa, uno mostraría claramente el vínculo entre ave y prácticas chamánicas. En una tableta, llamada "El Gran Sacerdote" (Figura 4), viene representado un personaje, probablemente un chamán o hombre de poder, en tres dimensiones con un felino a cada lado y con arriba de sus hombros dos aves rapaces que parecen proteger y al mismo tiempo empoderar el personaje (Laurencich-Minelli, 2011). En esta tableta de madera están modelados los típicos animales tutelares relacionados a la práctica chamánica (ave y felino), los mismos que, como hemos visto, se encuentran pintados juntos en los keros ceremoniales. En otras tabletas incluidas en la misma colección están esculpidos aves que parecen custodiar el instrumento ritual, mostrando sus vínculos con en estas prácticas.

El hallazgo de morteros, cubiletes, espátulas o cucharilla, tabletas y tubos en los Andes y sobre todo en el Desierto de Atacama en Chile, fue la prueba material de la existencia de prácticas alucinógenas en la cultura Tiwanaku (Berenguer, 1985). En realidad, los equipos inhalatorios encontrados alrededor del Lago Titicaca fueron una exigua cantidad en relación con los encontrados en Chile (Torres, 2004). Probablemente las condiciones climáticas del territorio, como las lluvias y la humedad, no permitieron la preservación de estos instrumentos hechos de material perecible. Durante mi investigación en el Museo cerámico Tiwanaku, encontré una sola tableta de hueso conservada con inciso un ser antropomorfo de pie con rasgos de felino en la parte superior. Los artesanos vaciaron la parte superior del hueso creando una especie de cajita, la cual se podía cerrar con una tapa hecha

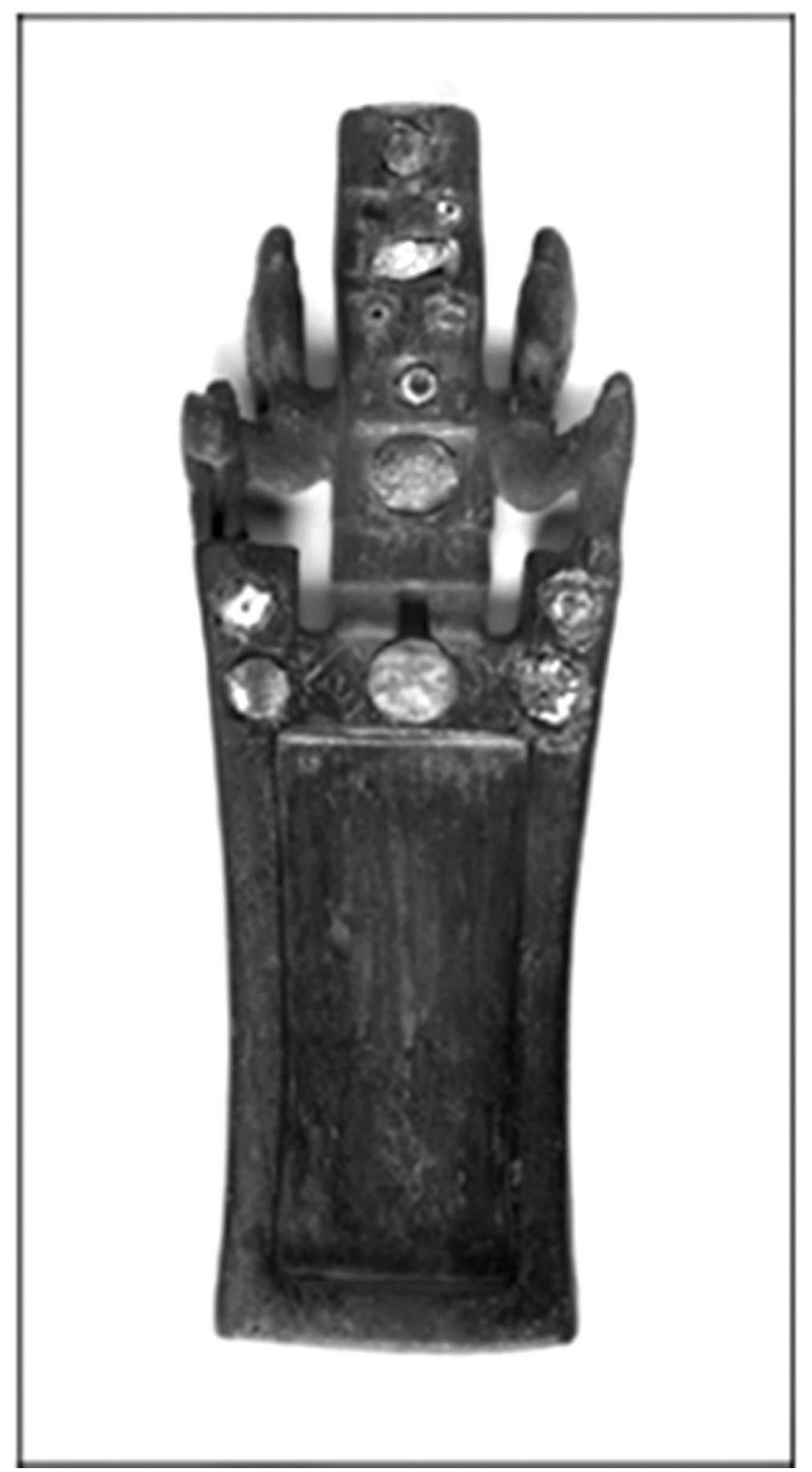

Figura 4 Tableta Inhalatoria Tiwanaku (Atacama) "El Gran Sacerdote". Colección Campagner, Treviso, Italia (Fotografía Laurencich Minelli)

a medida, donde se conservaba el polvo psicoactivo. El centro de este instrumento fue modelado en forma cóncava para mezclar los polvos psicotrópicos. La parte inferior del hueso tiene un orificio creado probablemente para aspirar la substancia psicoactiva o consumirla diluida con algún líquido, que también se podía cerrar con otra tapa de hueso (Figura 5).

Según el análisis iconográfico de Berenguer, la existencia e importancia de las prácticas chamánicas en la cultura Tiwanaku estaría grabada en algunas 


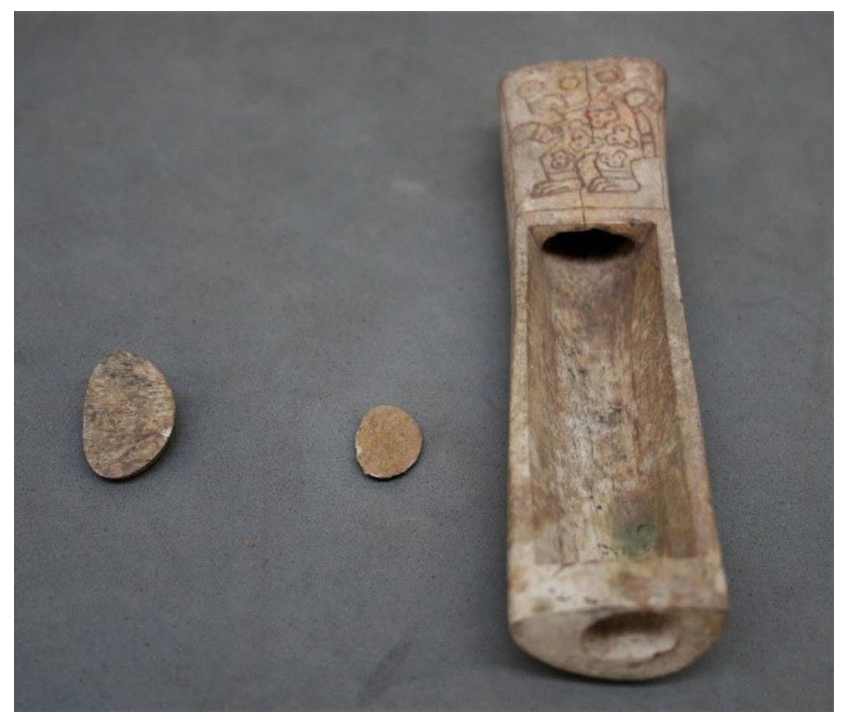

Figura 5 Tableta Inhalatoria Tiwanaku, Época IV-V. Museo de la Cerámica, Tiahuanaco. La Paz, Bolivia (Fotografía Elisa Cont)

litoesculturas. En los Monolitos Bennett y Ponce el personaje principal estaría llevando en sus manos dos instrumentos rituales; en la mano izquierda sostiene un keru y en la mano derecha una tableta inhalatoria. Además, estos instrumentos rituales podrían estar también representados en otro material lítico Tiwanaku, como en el Monolito Kochamama y en la mano de los personajes alados de perfil de la Puerta del Sol (Berenguer, 1985).

\section{Representaciones de seres antropomorfos y elementos aviarios}

Los sacerdotes o chamanes eran considerados por la sociedad tiwanakota los únicos que podían comunicarse con los tres planos del mundo y fungir de intermediarios entre los hombres y las deidades. Estos personajes poderosos buscaban relacionarse con las divinidades a través de la ayuda de algunos animales que se consideraban complementarios a los hombres. El chamán mediante el utilizo de substancias psicotrópicas alcanzaba la capacidad de mimesis con otros animales. Las imágenes tiwanakotas de seres antropomorfos mostrarían el fuerte vínculo entre la esfera humana y animal, típico aspecto del dualismo andino. Esta fusión y relación de reciproca dependencia viene representada a través la imagen de seres zooantropomorfos, que simbolizarían el Chamán en el acto de intercambiar sus fuerzas con las de los animales, durante la celebración de rituales. En las imágenes tiwanakotas los elementos animales simbolizan sus estrictos vínculos
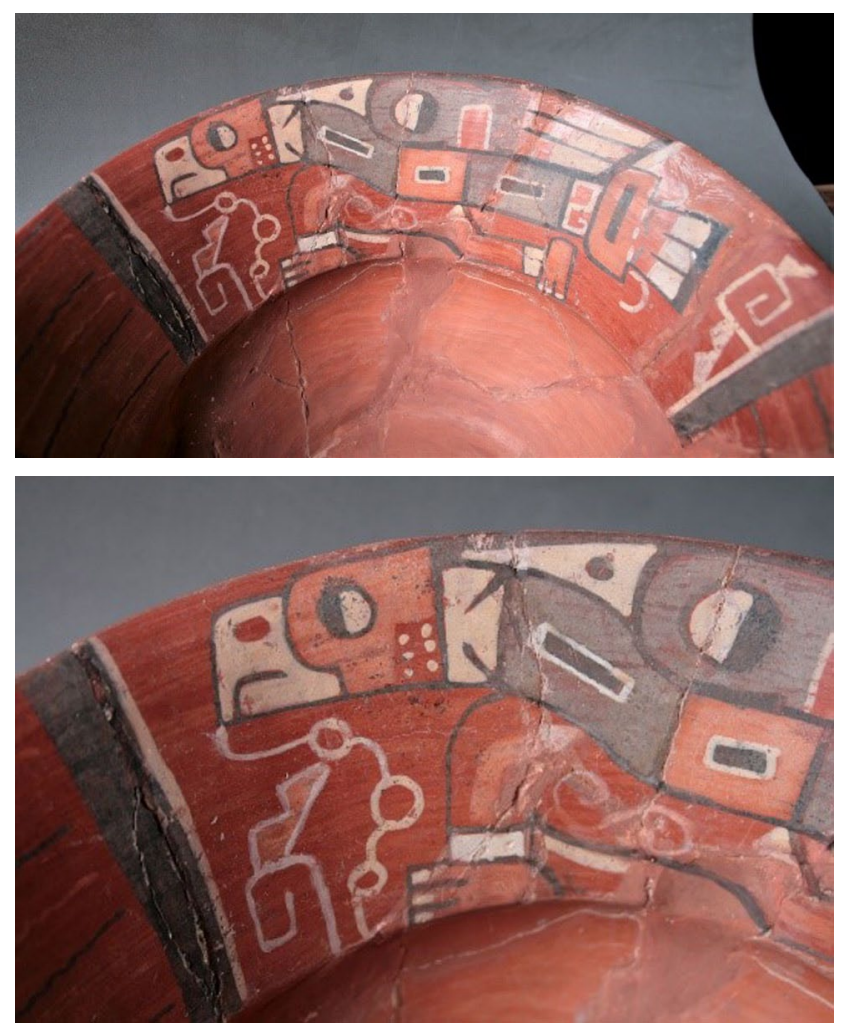

Figuras $6 \mathbf{a}$ y $\mathbf{6 b}$ Tazón Tiwanaku, Època IV. Colección Fritzbuch, Museo Metales Preciosos, La Paz (Fotografía Elisa Cont)

con la naturaleza y el paisaje ya que, en el imaginario colectivo, cada animal estaba relacionado a un mundo: el cóndor o ave al mundo de arriba "Alajpacha", el felino al mundo terrenal "Akapacha" y la serpiente o pez al mundo subterráneo o subacuático el "Mankhapacha" (Cont, 2018; Venturoli, 2014; Laurencich, 2001). En consecuencia, los diferentes iconos de animales figurarían la cosmovisión tiwanakota. También, como escribe Paredes, estos animales sagrados fueron considerados protectores y defensores de las comunidades (Paredes, 1995).

Los seres zoo-antropomorfos Tiwanaku que analicé, pintados en material cerámico, llevan muchos elementos aviarios: las alas, con "ojo a mitad" puesto en el centro, y la cola, ambas dotadas de tres plumas blancas. La cabeza también puede representar un ave, identificada por su típico pico y sin cresta. Según Berenguer, numerosas imágenes de seres antropomorfos representarían acciones típicas vinculadas al consumo de sustancias psicotrópicas: ojos a mitad, con rodilla en el suelo o en posición de correr (Figuras 6a y 6b). En cada pieza cerámica analizada están pintadas en simetría dos seres zoo-antropomorfos, que parecen representar el mismo personaje, 
pero con algunos elementos diferentes. En las figuras $6 \mathrm{a}$ y $6 \mathrm{~b}$ vemos que el mismo personaje con rasgos aviarios está representado dos veces, en un lado lleva en su pico un hilo con tres círculos y en el otro lado el personaje tiene en el pico el hilo con solo dos círculos, el tercer circulo se encuentra pintado abajo, entre sus piernas. Esta, como otras imágenes analizadas podría representar el mismo ser en dos momentos diferentes, y/o registrar una acción hecha por el personaje. Una hipotesis de interpretación apuntaría a la representación de una práctica chamánica. El hilo con círculos que sale de los picos recuerda en su forma estilizada el fruto de la Huilca o Cebil y podría representar su consumo. Otro posible significado de estas imágenes es que simbolicen un código numerológico caracterizado por los números 3,2 y 1 atribuyéndoles algún tipo de significado todavía desconocido. De acuerdo con el hipotesis de los estudiosos Laurencich y Zuidema comparto la idea de que muchas figuras geométricas en la iconografía tiwanakota podrían simbolizar números (Laurencich, 2011; Zuidema, 1977). Sin duda quedan muchos estudios por delante que podrán aclarar el significado de estos elementos.

Otras culturas andinas como la Moche y la Nazca utilizaron la representación de seres antropomorfos dotados de elementos aviarios para simbolizar el uso de substancias psicotrópicas. En la cultura Moche existen relatos como la "Leyenda sobre el nacimiento de la brujería" escrito por León Barandiarán, en los cuales se describen prácticas chamánicas en donde el brujo se trasformaba en águila tras ingerir una sustancia psicotrópica y la descripción de rituales propiciatorios para llamar la lluvia (María Luisa Sánchez David, 2011). En numerosas imágenes Moche se representan personajes con alas listos para sus vuelos chamánicos, imágenes que recuerdan las representaciones de seres antropomorfos en la iconografía Tiwanaku.

\section{El vuelo chamánico en la iconografía Tiwanaku}

Una imagen típica del chamanismo es el vuelo, que representa la capacidad de transitar en diferentes mundos y espacios temporales creando un vínculo entre ellos. En la cultura Tiwanaku los elementos aviarios fueron considerados símbolos del vuelo y de poder por atravesar las fronteras entre los mundos. Según la antropóloga Llamazares, la capacidad de las aves de cruzar los tres planos cósmicos, tenía una estrecha relación simbólica con el poder del chamán de cruzar las fronteras entre los mundos por medio de prácticas chamánicas (Llamazares, 2004).
El vuelo chamánico en varias culturas precolombinas viene representado a través de seres zoo-antropomorfos, con atributos de aves o decorados con elementos plumarios, que flotan en sentido horizontal. Simbolizarían el chamán en su estado de trance y realizando su viaje mágico. En la iconografía Tiwanaku se encontraron escasos ejemplos de representaciones de vuelo chamánico, pero, las imágenes que tenemos poseen las mismas características aquí descritas. Las más conocidas son las representaciones grabadas en el Dintel Kantatayita ubicado en el centro Ceremonial de Tiwanaku y en el Dintel Linares conservado en el Museo MUNARQ de La Paz. Ambos los dinteles representarían seres antropomorfos con rasgos de felinos (llamados también sacrificadores) en vuelo. La litoescultura de Kantatayita es un arco rebajado que exhibe un bajorrelieve, desafortunadamente muy desgastado con seis personajes voladores, tres volando hacia el centro desde la parte derecha y tres hacia el centro desde la izquierda, todos llevando hachas y cabezas trofeos en las manos. El dintel Linares fue construido posteriormente a la pieza de Kantatayita y representaría cuatro personajes antropomorfos voladores de perfil; dos avanzando hacia el centro desde la parte derecha y dos hacía el centro desde la parte izquierda, todos con un objeto en las manos que recordaría, por su forma, la típica bolsita de equipo inhalatorio (tubos y tabletas) utilizado en las prácticas chamánicas. En el centro está la imagen de un ser puesto de frente sujetando un báculo en ambas manos, probablemente representando la "Deidad de los Báculos". Este dintel mostraría una ulterior evidencia, que se suma a las estudiadas por Berenguer, de prácticas chamánicas representadas en material lítico, caracterizadas además por personajes en vuelo (ob.cit.).

Conservada en los almacenes del Museo Cerámico de Tiahuanaco encontré una entre las únicas piezas en cerámica, un kero, con pintados hombres voladores en la parte superior al añillo de decantación, lamentablemente muy desgastado y sin informaciones sobre su hallazgo. En la imagen se pueden observar unos personajes antropomorfos flotando de perfil con un báculo en la mano derecha y un hacha en la mano izquierda, y a sus pies izquierdos está atada una cabeza trofeo. Los seres voladores llevan elementos plumarios, ojos alados, varios detalles corporales que recuerdan el signo escalonado, estilización del ave, y algunas calaveras. A través de las imágenes de seres flotantes los artesanos de Tiwanaku representaban el poder típico de las aves, el vuelo, mostrando un estado de trance y la destinación de los viajes de estos personajes. Este keru parece figurar unos 


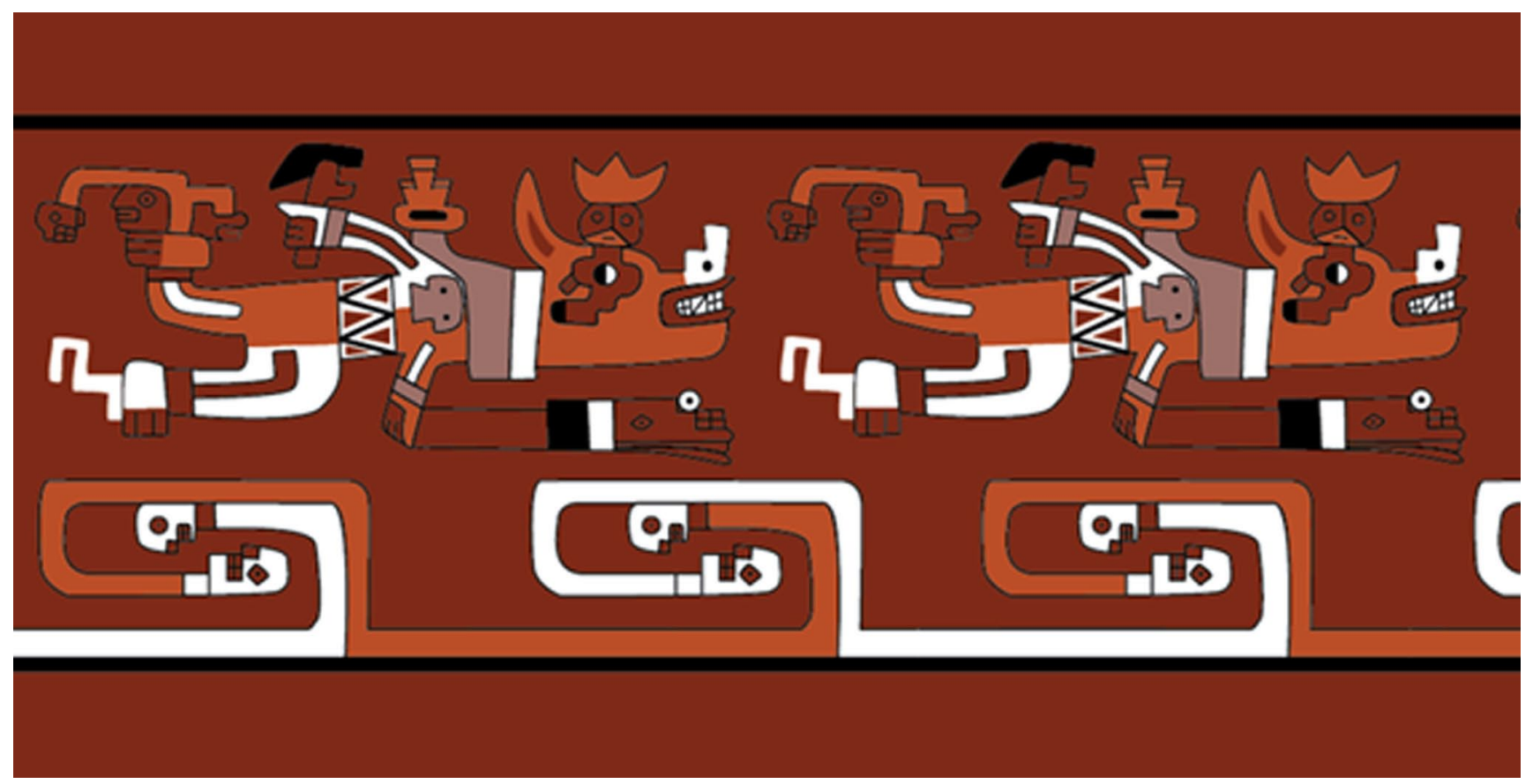

Figura 7 Iconografía Keru Tiwanaku. Época IV-V. Dibujo hecho por Guido Mamani Pillco. Depósitos, Tiahuanaco. La Paz, Bolivia

chamanes viajando por el mundo de los antepasados, el mankhapacha, simbolizado por las calaveras puestas al termine de los signos en forma de meandros (Figura 7).

Recientemente dos arqueólogos bolivianos, Trigo y Hidalgo analizaron en un estudio dos fragmentos de keru muy parecidos a esta pieza, encontrados en el templo de Putuni en Tiwanaku (Trigo y Hidalgo, 2018). La representación del vuelo no suele ser un hallazgo muy común en el material Tiwanaku encontrado hasta hoy en día, pero se puede confirmar que sus artistas utilizaron diferente material (lítico, cerámico y textil) donde grabar este estado chamánico.

Estas representaciones de hombres voladores recordarían además algunas imágenes presentes en el arte Nazca, demostrando un contacto e influencias entre esta cultura y la de Tiwanaku.

Recientes estudios antropológicos e iconográficos realizados por Eva Fisher demostrarían que sigue vigente en algunas comunidades de Bolivia la antigua concepción de las aves consideradas capaces de atravesar fronteras entre los mundos. Los resultados de sus análisis sobre los iconos de aves en materiales textiles de algunas comunidades Kallawaya de Bolivia, demostrarían la existencia de diferentes especies representadas, distinguibles por sus diferentes características y portadoras de diferentes significados. Según sus estudios las falcónidas serían consideradas mediadoras entre planes del mundo y simbolizarían la fuerza física junta al poder espiritual, mientras los cóndores representarían los mensajeros entre hombres y ancestros y estarían vinculados a el agua y a las lluvias (Eva Fisher, 2006).

\section{El icono del ojo alado u ojo llorón}

El ojo alado es un ulterior ejemplo del estilo naturalista Tiwanaku en el cual el artista representa elementos escogidos de su entorno natural y los trasforma en símbolos, asignándoles significados sagrados. En la cuenca del Lago Titicaca se encuentran actualmente unas especies residentes de aves que se distinguen por tener alrededor de sus ojos unas manchas muy parecidas al característico ojo alado o llorón presente en la iconografía Tiwanaku. Estas especies son el Falco Sparverius y el Falco Femoralis que como todas las aves rapaces se caracterizan por tener una aguda vista y grandes ojos en relación con el tamaño corporal.

El motivo del ojo alado o llorón es muy frecuente en la iconografía Tiwanaku, y se representa como un ojo con una forma de ala a su alrededor y con ninguno o hasta tres círculos o lagrimas debajo del ojo. Este icono se encuentra grabado en la cara de personajes a figura entera, en imágenes de cabezas de perfil (cabezas sueltas) o en 
forma de ala dotada de ojo en seres zoo-antropomorfos y mostraría la concepción Tiwanakota de un fuerte vínculo entre ojo y alas. Esta relación entre el icono del ojo y vuelo podría tener una explicación gracias a unos estudios desarrollados por Torres sobre los efectos fisiológicos y las alucinaciones que provoca la Anadenanthera Colubrina (Torres, 2001). Visiones mágicas que habrían sido concebidas como experiencias divinas. El chamán durante su trance adquiere la capacidad de volar, propias de halcones y vultúridas, y la posibilidad de ver otros mundos. El símbolo del ojo alado o lagrimón se interpretaría como un signo distintivo de los hombres con una cierta autoridad y poder, que marcaría un rol específico en la sociedad y de consecuencia mostraría una estructura de la sociedad tiwanakota.

Los ojos lagrimones además de simbolizar el consumo de alucinógenos por parte de personas de poder, podrían tener un vínculo con la lluvia, y simbolizar lágrimas que fertilizan la tierra (Cossío del Pomar, 1971). El nexo entre lágrimas y lluvias podría ser documentado por el cronista Guamán Poma, el cual describe en sus escritos un ritual a través del cual los hombres solían pedir a las divinidades agua o mejores condiciones yendo a las montañas y llorando para asegurarse un buen cultivo. El cronista anota que en temporadas de sequía o heladas los hombres "an de andar por los serros llorando y pidiendo agua a dios pachacamac todos los indios grandes como mujeres o muchachos..." (Murra, 1987; Guamán Poma, 1613, 1936). El número de los círculos abajo el ojo, que representarían las lágrimas, podría tener además otro significado vinculado a su cantidad. La misma cantidad, de cero a tres, viene grabada cerca de varios elementos, alas, seres antropomorfos, ojos, anteriormente analizados. Se supone así que a estos números podrían pertenecer significados fundamentales para la interpretación de la iconografía Tiwanaku.

Según Smith el icono del ojo alado podría estar relacionado también a las lagunas de los cerros, las paqarinas, consideradas los "ojos de las montañas y puertas a los otros mundos" en donde tiene origen la fertilidad. Las aves que residen en estas lagunas tendrían la capacidad de atravesarlas y pedir lluvias o su interrupción (Smith, 2011). Viene documentada la relación entre aves y agua también por el sociólogo Paredes, el cual documenta la creencia, en algunas comunidades Kollas, que algunas especies de aves simbolizarían, mediante sus comportamientos, la llegada de las lluvias o vientos (Paredes, 1995). A través estos símbolos el artista tiwanakota mostraría el poder del ave relacionado al poder del chamán, representando una forma de comunicación a través los mundos para pedir fertilidad de los cultivos.

\section{Conclusiones}

En el estudio iconográfico descrito en este artículo emerge el estrecho vínculo entre el símbolo del ave y las prácticas chamánicas. Icono que, representado en objetos ceremoniales, les otorgaba carácter sagrado y que indicaría una precisa ideología y cosmovisión. Los dinteles líticos, los instrumentos y las indumentarias rituales fueron considerados puertas, o sea medios sagrados a través de los cuales los sacerdotes podían cambiar su estado y empezar su viaje mágico. Emerge además que, como en otras culturas precolombinas (Moche y Nazca), las aves en la cultura Tiwanaku eran animales relacionados a la fertilidad. Estos animales guías ayudaban al chamán en su vuelo para comunicarse con las divinidades al fin de pedir la lluvia o su interrupción. Se demuestra así que cada icono en el arte Tiwanaku tiene características con múltiples significados y vínculos específicos, algunas además relacionadas con un código numérico. La iconografía para los Tiwanakotas fue una forma de comunicación hermética entre hombres iniciados y divinidades, bajo normas sagradas. Concluyendo, los símbolos en el arte Tiwanaku demostrarían la toma de consciencia existencial del hombre respecto al cosmos, y al mismo tiempo expresarían una voluntad de sentirse parte activa en ello.

\section{Bibliografía}

ALBARRACIN-JORDAN, J., M, CAPRILES, J., J. MILLER, M., 2014. Transformación en la práctica ritual e interacción social en la periferia de Tiwanaku, Revista de Arqueología Boliviana №58: pp.58-66

BERENGUER RODRÍGUEZ, J., 2000. Tiwanaku. Señores del Lago Sagrado. Museo Chileno de Arte Precolombino. Santiago

BERENGUER RODRÍGUEZ, J., 1985. Evidencia de inhalación de alucinógenos en esculturas Tiwanaku. Revista Chungará №14. Universidad de Tarapacá, Arica-Chile: pp. 61-69

BERENGUER RODRÍGUEZ, J., 1987.Consumo Nasal de Alucinógenos en Tiwanaku: una aproximación iconográfica. Boletín Chileno de Arte Precolombino, №2, pp. 33-53, Santiago de Chile (1987)

BLASCO BOSQUED, C., RAMOS GÓMEZ, L. J., 1980. Cerámica Nazca. Seminario Americanista de la Universidad de Valladolid. Valladolid 
CARLSON, U. Y DIENSTEL, H., 2016. Tierra, agua, hombre y dioses. Símbolos de orientación en obras maestras textiles del antiguo Perú. Ed. FEMO Selbstverlag

CONT, E., 2018. La iconografía de la serpiente en la cultura Tiwanaku en Arte y Patrimonio Cultural: Memoria del 56응 Congreso de Americanistas pp.928-937 Ed. Universidad de Salamanca

COSSÍO DEL POMAR, F., 1971 La cosmomagía de Tiwanaku, pp. 17-31 Arte del Antiguo Perú, Barcelona 1971. Ed. Polígrafa S.A.

COSTAS, M.P., 2018 La iconografía de las cabezas trofeo en la producción plástica de las sociedades prehispánicas del noroeste argentino: problemas en torno a su definición y significación. Arte y Patrimonio Cultural: Memoria del 56음 Congreso de Americanistas pp.94-108 Ed. Universidad de Salamanca

ELIADE, M., 2007. Immagini e Simboli, Ed. Jaca Book SpA, Milano

ELIADE, M., 1974. Tratado de historia de las religiones, Vol. I-II. Ed. Cristiandad. Madrid

FISHER, E., 2006. La iconografía de las aves en el contexto textil andino: aspectos regionales, trans-religionales, históricos y actuales. ACTAS, III Jornadas internacionales sobre Textiles Precolombinos Victòria Solanilla Demestre. (ed.) Grup d'estudis Precolombins, UAB. Barcelona

HUANCA APAZA, GROBERT Á., 2018. El dintel Linares: el rencuentro de una pieza clave Tiwanaku. Temas iconográficos de la cuenca del Titicaca. Arqueología Boliviana, №4, pp. 67-89 Ed. Ministerio de Cultura y Turismo, Unidad de Arqueología y Museos, Museo Nacional,

KAUFFMANN DOIG, F., 1978. Manual de Arqueología Peruana. Ed. Iberia. Lima, Perú

LAURENCICH MINELLI, L., 2011. Ofrendas Atacameñas en la colección de Monseñor Campagner (Treviso, Italia) Estudios Atacameños №41: pp. 45-62.

LLAGOSTERA, A., 2006. Contextualización e iconografía de las tabletas psicotrópicas Tiwanaku de San Pedro de Atacama, Volumen 38, №1. Revista de Antropología Chilena Chungara, Chile: pp. 83-111
LLAMAZARES, A. M. Y MARTÉINEZ SARASOLA, C., 2004. El lenguaje de los dioses. Arte, chamanismo y cosmovisión indígena en Sud América. Ed. Biblos, Buenos Aires

MAMANI, P., 2003. Simbología y poder indígena después de los Kataris-Amarus y Willkas. Centro de Documentación Mapuche, AymaraNet Archives.

MURRA, J. La organización económica del Estado Inca, 1987. Siglo Veintiuno Sa de Cv Editores, Instituto de Estudios Peruano, Colección América Nuestra. México D.F.

PAREDES, M. R., 1995 Mitos, supersticiones y supervivencias populares de Bolivia, Ediciones ISLA, La Paz, Bolivia

PULIDO CAPURRO, V., 2018. Estacionalidad de las especies de aves residentes y migratorias altoandinas en el lado peruano de la cuenca del Titicaca. Rev. investig. Altoandina vol.20 no.4 Puno

SÁNCHEZ CANEDO, W.; BUSTAMANTE TOJAS, M. Y VILLANUEVA CRIALES, J., 2016. La chuwa del cielo. Los animales celestiales y ciclo anual altiplánico desde la bibliografía social de un objeto, pp.9-25 Musef, La Paz, Bolivia

SÁNCHEZ DAVID, M. L., 2011. El rol chamánico en la cultura Moche: ¿Adivino, curandero, Brujo o Sacerdote? Las imágenes precolombinas: reflejos de saberes, pp.517-543 México, D.F. Ed. Universidad Autónoma de México

SONDEREGUER, C., 2003. Manual de Iconografía precolombina y su análisis morfológico. Liberarías Juan O’Gorman Nobuko Buenos Aires, Argentina

SONDEREGUER, C., 1997. Estética Amerindia. Ed. Estudio Sigma Buenos Aires, Argentina

M. TORRES, C., 2001. Iconografía Tiwanaku en la parafernalia inhalatoria de los Andes Centro-Sur. Boletín de Arqueología PUCP, №5: pp. 427-454.

M. TORRES, C., 2004. Imágenes legibles: la iconografía Tiwanaku como significante Boletín del museo chileno de arte precolombino $\mathrm{N}^{\circ}$ 9. Santiago de Chile: pp. 55-73

VILLANUEVA CRÍALES, J., 2015. Aves doradas, plantas plumarias y ojos alados. Vías para interpretar la iconografía aviaria Tiwanaku. La rebelión de los objetos. Arte Plumario. Anales de la reunión anual de etnología. Musef. La Paz: pp.233-244 